\title{
Effect of water deficiency and potassium application on plant growth, osmolytes and grain yield of Brassica napus cultivars
}

\author{
Murad Ali ${ }^{1}$, Jehan BaKht ${ }^{2 *}$, Gul Daraz Khan ${ }^{1}$ \\ ${ }^{1}$ Department of Water Management, The University of Agriculture, Peshawar, Pakistan \\ ${ }^{2}$ Institute of Biotechnology and Genetic Engineering, The University of Agriculture, \\ Peshawar, Pakistan
}

\begin{abstract}
One of the major issues with brassica oil seed production is the water requirement of the brassica crop. To address the problem, field experiments were conducted to evaluate the effect of potassium $(\mathrm{K})$ and water deficiency levels on canola (Brassica napus L.). Analysis of the data revealed that application of $\mathrm{K}$, irrigation and interactions between irrigation and cultivar $(\mathrm{I} \times \mathrm{C})$, irrigation and potassium $(\mathrm{I} \times \mathrm{K})$, potassium and cultivar $(\mathrm{K}$ $\times \mathrm{C})$, and irrigation and cultivar and potassium $(\mathrm{I} \times \mathrm{C} \times \mathrm{K})$ had a significant $(\mathrm{p}<0.05)$ effect on shoot proline content, relative water content, plant fresh weight and grain yield. Potassium application, irrigation and interaction between $\mathrm{I} \times \mathrm{C}, \mathrm{K} \times \mathrm{C}$, and $\mathrm{I} \times \mathrm{C} \times \mathrm{K}$ had a significant $(\mathrm{p}<0.05)$ effect on shoot sugar content. Water deficiency increased shoot proline and sugar contents and decreased relative water content. Potassium application increased shoot proline level in a dose dependent manner. Minimum proline and sugar contents and maximum relative water content, plant fresh and dry weight and yield were obtained when $100 \%$ irrigation was applied. Maximum grain yield was obtained upon application of $100 \%$ irrigation in combination with $120 \mathrm{~kg} \mathrm{ha}^{-1} \mathrm{~K}$.
\end{abstract}

Keywords: Brassica napus, grain yield, potassium, proline, relative water content, water deficiency

\section{Introduction}

Plants can cope with drought stress through genetic and adaptive mechanisms. Plants possess the mechanisms to escape, avoid and/or resist to drought. They can also escape drought by adjusting their physiological and biochemical development according to the availability of water in their habitat (ARRAUDEAU 1989). Water stress induces a significant decrease in metabolic factors such as decrease in chlorophyll content and enhanced accumu-

* Corresponding author, e-mail: jehanbakht@yahoo.co.uk 
lation of proline (GIBON et al. 2000, Din et al. 2011). Free proline accumulation and sugar in high concentration under abiotic stress has been reported to have an adaptive mechanism (SARKer et al. 1999, Ronde et al. 2004, Sofo et al. 2004, Monreal et al. 2007, JAVAdi et al. 2008, Keyvan, 2010, Mafakheri et al. 2010, Moustakas et al. 2011, BaKht et al. 2013). Potassium plays a vital role in photosynthesis, translocation of photosynthates, protein synthesis, control of ionic balance, regulation of plant stomata and water use, activation of plant enzymes and many other processes (REDDY et al. 2004). Potassium is not only an essential macronutrient for plant growth and development, but also a primary osmoticum in the maintenance of the low water potential of plant tissues. Therefore, accumulation of $\mathrm{K}$ in plant tissues under drought stress may play an important role in water uptake along a soil-plant gradient (GLENN and BROwn 1998).

The accumulation and release of potassium by stomatal guard cells lead to changes in their turgor, resulting in stomatal opening and closing (OuTLAW 1983). In water-stressed plants, increased abscisic acid (ABA) levels are known to stimulate the release of potassium from guard cells, giving rise to stomatal closure (Assmann and SHIMAZAKi 1999). Numerous studies have shown that application of $\mathrm{K}$ fertilizer mitigates the adverse effects of drought on plant growth (ANDERSON et al. 1992, SANGAKKARA et al. 2001). FusHEING (2006) has revealed that the lower water loss from plants supplied with sufficient $\mathrm{K}$ is due to the reduction in transpiration, which not only depends on the osmotic potential of mesophyll cells, but is also controlled to a large extent by the opening and closing of stomata. The objective of this study was to test the effectiveness of potassium application in mitigation of water deficiency, with reference to the physiological changes like proline, sugar and relative water content in four canola cultivars. These findings could be used as screening basics for further study in breeding programs.

\section{Materials and Methods}

\section{Site description}

The experimental site of the University of Agriculture Peshawar KPK Pakistan is situated at $34^{\circ} \mathrm{N}, 72^{\circ} \mathrm{E}$ and an altitude of 290 meters above sea level. Field experiments were conducted at Malakandher Research Farm (The University Agricultural Peshawar, KPK Pakistan) using a randomized complete block design with split plot arrangement. Four cultivars of Brassica napus were investigated: 'Wester', 'Rainbow', 'Oscar', and 'Legend'. The following treatments were studied during the course of study: (1) irrigation levels: $100 \%$ replacement of evapotranspiration $\left(\mathrm{Et}_{\mathrm{a}}\right), 80 \%$ replacement of $\mathrm{ET}_{\mathrm{a}}$, and $60 \%$ replacement of $\mathrm{Et}_{\mathrm{a}}$; (2) potassium (K) levels: $60 \mathrm{~kg} \mathrm{ha}^{-1}(\mathrm{~K} 1), 90 \mathrm{~kg} \mathrm{ha}^{-1}(\mathrm{~K} 2)$, and $120 \mathrm{~kg} \mathrm{ha}^{-1}$ (K3).

\section{Biochemical analysis}

Moisture content was determined through the gravimetric method by taking samples at each treatment at 3 depths i.e. 0-30, 30-60 and 60-90 cm. The moisture content on mass and volume basis, bulk density, depth of water needed and duration of irrigation were determined as described by JAMES (1993). Moisture content was first determined on mass basis $\left(\theta_{\mathrm{m}}\right)$ and was converted to moisture content on volume basis $\left(\theta_{\mathrm{v}}\right)$ by multiplying with bulk density and dividing by water density. From this the depth of water needed was calculated for each treatment. Fresh and dry weights of all samples were determined two months after 
sowing. After the taking of fresh weight, plant samples were dried in an oven at $80{ }^{\circ} \mathrm{C}$ for three days to record plant dry weight. Plant height was measured two months after sowing. In each treatment, plant heights of three plants were measured in $\mathrm{cm}$ and then average values were calculated. Grain yield was calculated by threshing all pods of the plants in each treatment and then converted into grain yield $\mathrm{kg} \mathrm{ha}^{-1}$.

Shoot proline content was determined 60 days after sowing using the method of BATES et al. (1973) with minor modifications. Briefly, frozen plant material of $500 \mathrm{mg}$ was homogenized in $1.0 \mathrm{ml}$ of sterilized iron free water and centrifuged at $5000 \mathrm{rpm}$ for 5 minutes. Extract $(100 \mu \mathrm{l})$ was mixed with acid ninhydrin for $1 \mathrm{~h}$ at $100^{\circ} \mathrm{C}$ and the reaction was terminated in an ice bath. The reaction mixture was thoroughly shaken and the optical density was determined at $520 \mathrm{~nm}$. Level of shoot proline content was determined from a standard curve in the range of $0-20 \mu \mathrm{g} \mathrm{ml}^{-1}$ of L-proline.

Sugar concentration was measured 60 days after sowing as described by DuBoIs et al. (1956). Briefly, $20 \mathrm{mg}$ plant tissue was crushed in $4 \mathrm{ml}$ of extraction buffer, centrifuged for 5 minutes at $9000 \mathrm{rpm}$ and the pellet was re-extracted. Two ml each of chloroform and distilled water were added to the pooled supernatant. Two $\mathrm{ml}$ of the sample was mixed with 1 $\mathrm{ml}$ of distilled water, $1 \mathrm{ml}$ phenol $\left(\mathrm{C}_{6} \mathrm{H}_{5} \mathrm{OH}\right)(5 \%)$ and $5 \mathrm{ml}$ sulfuric acid. After the appearance of a dark pink color, the mixture was kept at $80^{\circ} \mathrm{C}$ for 30 minutes inside the oven. The samples were then shaken and placed in a water bath at $30{ }^{\circ} \mathrm{C}$ for 20 minutes and absorbance was measured at $490 \mathrm{~nm}$. Standard of D-glucose $(0,0.2,0.4,0.6,0.8 \mu \mathrm{mol})$ was also prepared using the same procedures.

Relative water contents were determined 60 days after sowing adopting the standard procedure of BAJJ et al. (2001). The leaf samples (about $5 \mathrm{~cm}^{2}$ each) from all the treatments were weighed to obtain fresh weight (FW). Turgid weight (TW) was measured by completely immersing the samples in distilled water and placing them in the dark at $4{ }^{\circ} \mathrm{C}$ for 24 h. The samples were blotted on filter paper and weighed. The samples were dried at $70{ }^{\circ} \mathrm{C}$ for $48 \mathrm{~h}$ and finally dry weight (DW) was obtained. Relative water content was calculated by the following formula:

$$
\mathrm{RWC}=[(\mathrm{FW}-\mathrm{DW}) /(\mathrm{TW}-\mathrm{DW})] \times 100
$$

\section{Statistical analysis}

Data were analyzed according to the randomized complete block (RCB) design with split plot arrangements using ANOVA (GoMEZ and GoMEZ 1984). MSTAT computer software was used for the analysis of the data (BRICKER 1991). Interaction between the variables was measured by analysis of variance. Differences in means were separated by the least significant difference (LSD) test (STEEL and ToRRIE 1997).

\section{Results}

\section{Plant growth and development}

Analysis of the data indicated that $\mathrm{K}$ application, irrigation and interaction between $\mathrm{I} \times$ $\mathrm{C}, \mathrm{I} \times \mathrm{K}, \mathrm{K} \times \mathrm{C}$, and $\mathrm{I} \times \mathrm{C} \times \mathrm{K}$ had a highly significant $(\mathrm{p}<0.01)$ effect on shoot fresh weight of canola (Fig. 1). Maximum shoot fresh weight was observed in $100 \%$ irrigated plants. Similarly, maximum shoot fresh weight was produced by the 'Legend' when $100 \%$ irriga- 


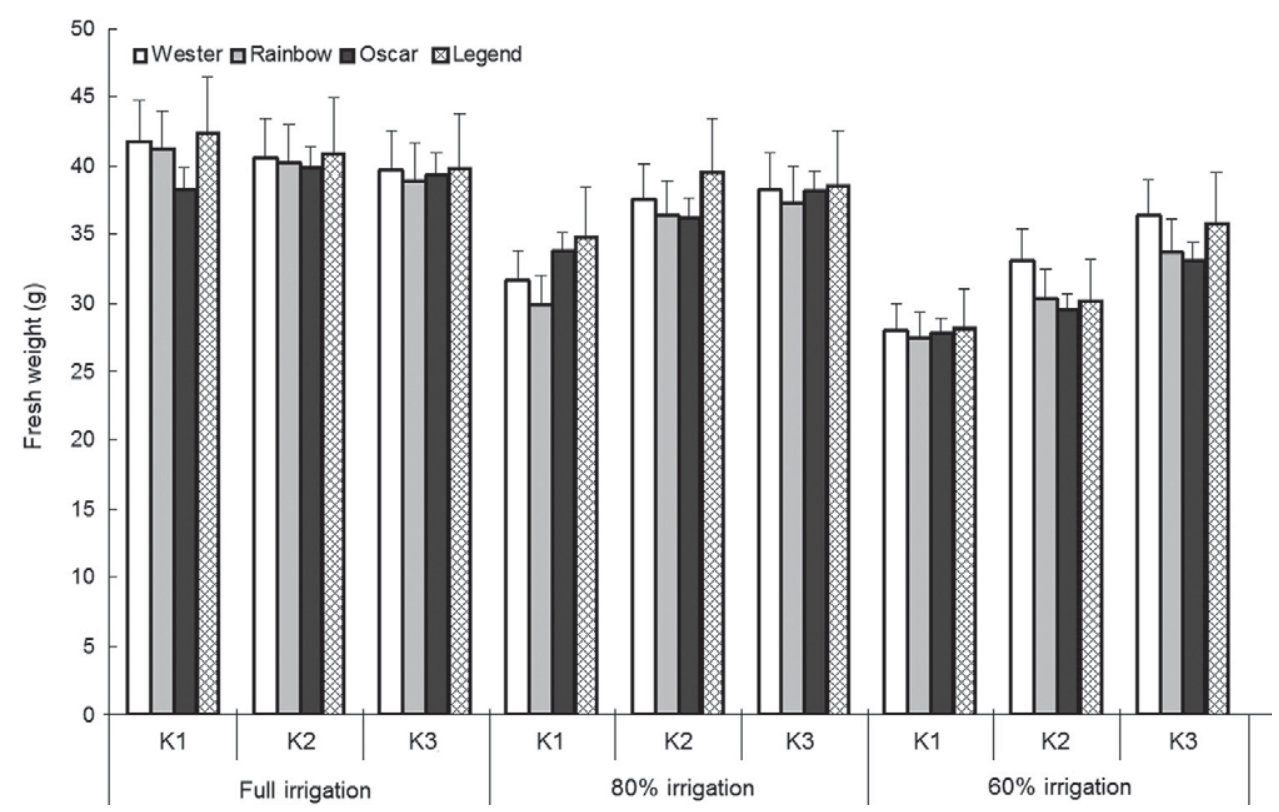

Fig. 1. Effect of water deficiency and potassium application and their interactions on shoot fresh weight (g) 60 days after sowing of Brassica napus cultivars ('Wester', 'Rainbow', 'Oscar' and 'Legend'). Potassium application: $60 \mathrm{~kg} \mathrm{ha}^{-1}$ (K1), $90 \mathrm{~kg} \mathrm{ha}^{-1}$ (K2), and $120 \mathrm{~kg} \mathrm{ha}^{-1}$ (K3). Bar represents \pm LSD at $\mathrm{p}<0.05$.

tion of actual evapotranspiration was applied. In the case of potassium treatments, maximum shoot fresh weight was gained by plants treated with $120 \mathrm{~kg} \mathrm{~K} \mathrm{ha}^{-1}$. Further, 'Wester' produced maximum shoot fresh weight when treated with $120 \mathrm{~kg} \mathrm{~K} \mathrm{ha}^{-1}$. Interaction between $\mathrm{I} \times \mathrm{K}$ showed that maximum shoot fresh weight was produced by the 'Legend' at $100 \%$ irrigation level and $60 \mathrm{~kg} \mathrm{~K} \mathrm{ha}^{-1}$. Irrigation, cultivars and interaction between $\mathrm{I} \times \mathrm{C}$ had a significant $(\mathrm{p}<0.01)$ effect on shoot dry weight of canola whereas the effect of $\mathrm{K}$ application and all other interactions were non-significant ( $p>0.05)$ (Fig. 2). Maximum shoot dry weight was observed in those treatments where a 100\% irrigation level was applied. Similarly, maximum shoot dry weight was produced by 'Legend' when $100 \%$ irrigation of actual evapotranspiration was applied. Analysis of the data revealed that irrigation application and interaction of $\mathrm{I} \times \mathrm{C} \times \mathrm{K}$ had a significant $(\mathrm{p}<0.01)$ effect on plant height 60 days after sowing and at physiological maturity (Fig. 3). The effect of $\mathrm{K}$ application and all other interactions were non-significant $(\mathrm{p}>0.05)$. Taller plants were observed in those treatments where $100 \%$ irrigation was applied followed by $80 \%$ irrigation level. Cultivars 'Rainbow' and 'Legend' attained maximum plant height when treated with 100\% irrigation level. Potassium application produced non-significantly taller plants in those treatments where 120 $\mathrm{kg} \mathrm{K} \mathrm{ha}{ }^{-1}$ was applied. Maximum plant height was noted in 'Wester' and 'Rainbow' when they were treated with $120 \mathrm{~kg} \mathrm{~K} \mathrm{ha}^{-1}$. I $\times \mathrm{K}$ interaction revealed maximum plant height in $100 \%$ irrigated plants treated with $60 \mathrm{~kg} \mathrm{~K} \mathrm{ha}^{-1}$. 


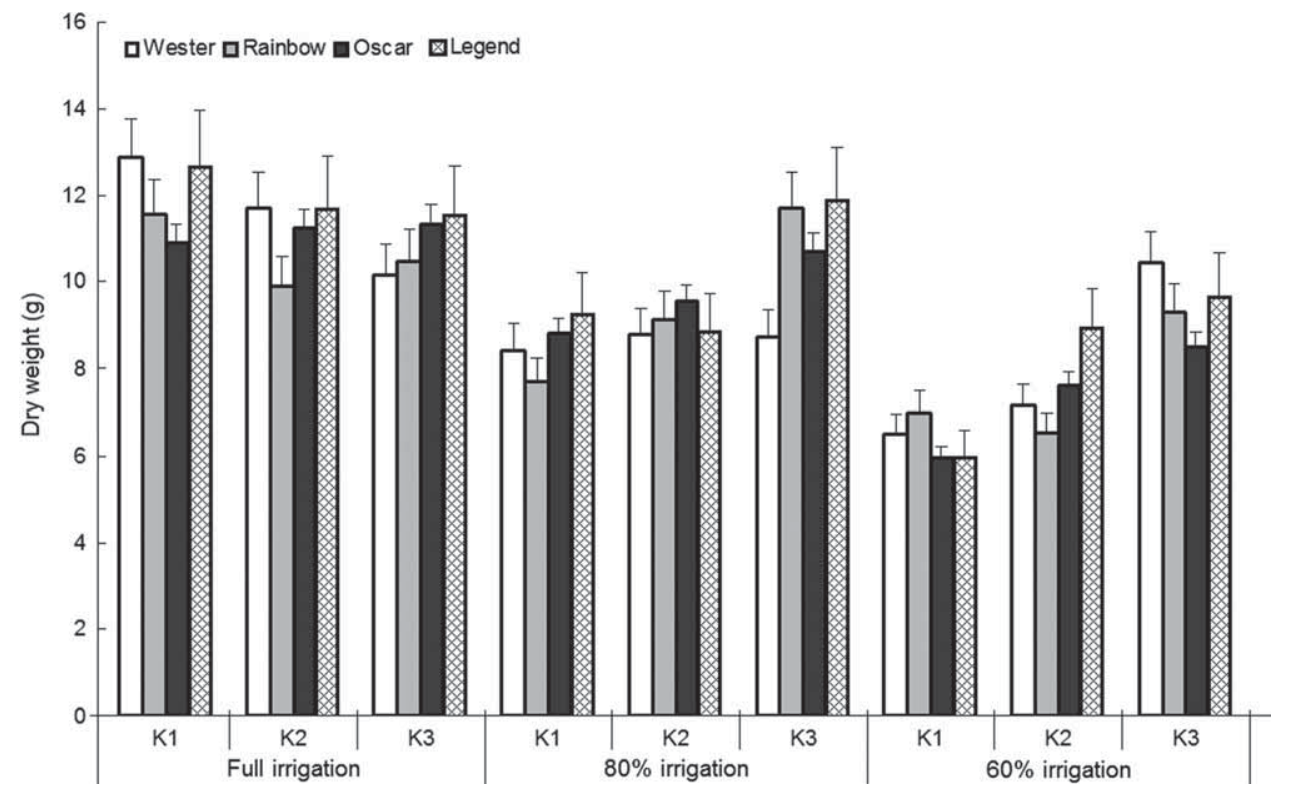

Fig. 2. Effect of water deficiency and potassium application and their interaction on shoot dry weight (g) 60 days after sowing of Brassica napus cultivars ('Wester', 'Rainbow', 'Oscar' and 'Legend'). Potassium application: $60 \mathrm{~kg} \mathrm{ha}^{-1}(\mathrm{~K} 1), 90 \mathrm{~kg} \mathrm{ha}^{-1}$ (K2), and $120 \mathrm{~kg} \mathrm{ha}^{-1}$ (K3). Bar represents \pm LSD at $p<0.05$.

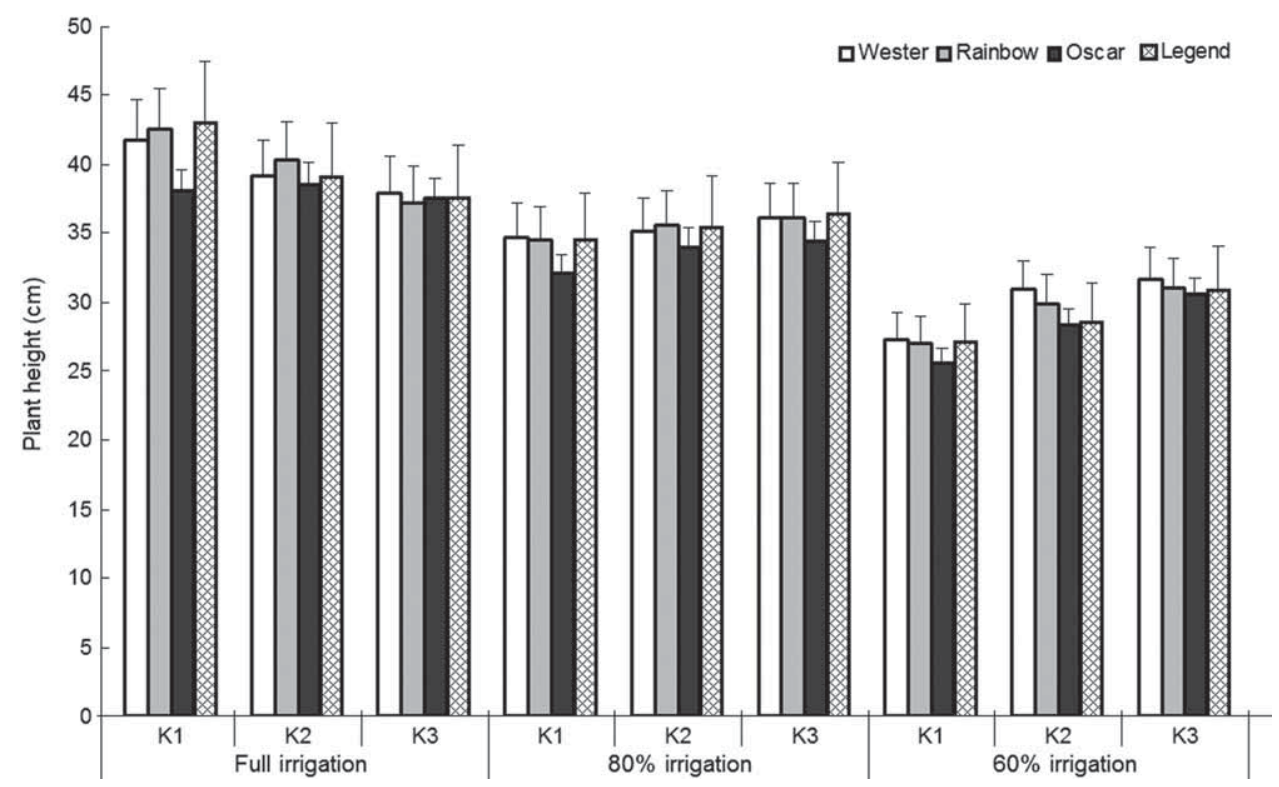

Fig. 3. Effect of water deficiency and potassium application and their interactions on plant height (cm) after 60 days of sowing of Brassica napus cultivars ('Wester', 'Rainbow', 'Oscar' and 'Legend'). Potassium application: $60 \mathrm{~kg} \mathrm{ha}^{-1}$ (K1), $90 \mathrm{~kg} \mathrm{ha}^{-1}$ (K2), and $120 \mathrm{~kg} \mathrm{ha}^{-1}(\mathrm{~K} 3)$. Bar represents \pm LSD at $\mathrm{p}<0.05$. 


\section{Shoot proline}

Statistical analysis of the data revealed that the application of $\mathrm{K}$, irrigation and interaction between $\mathrm{I} \times \mathrm{C}, \mathrm{I} \times \mathrm{K}, \mathrm{K} \times \mathrm{C}$ and $\mathrm{I} \times \mathrm{C} \times \mathrm{K}$ had a significant $(\mathrm{p}<0.01)$ effect on shoot proline content of B. napus (Fig. 4). Maximum shoot proline content was observed in those treatments where $60 \%$ irrigation of actual evapotranspiration $\left(\mathrm{ET}_{\mathrm{a}}\right)$ was applied. Maximum shoot proline content was produced by 'Rainbow' at 60\% irrigation of actual evapotranspiration. Similarly, K application also increased proline concentration in all cultivars in a dose dependent manner, although, the magnitude of increase varied among the different cultivars. Maximum shoot proline content was noted in plants treated with $120 \mathrm{~kg} \mathrm{~K} \mathrm{ha}^{-1}$. Our results also indicated that maximum shoot proline content was produced in plants treated with $60 \%$ irrigation of actual evapotranspiration $\left(\mathrm{ET}_{\mathrm{a}}\right)$ and $120 \mathrm{~kg} \mathrm{~K} \mathrm{ha}^{-1}$.

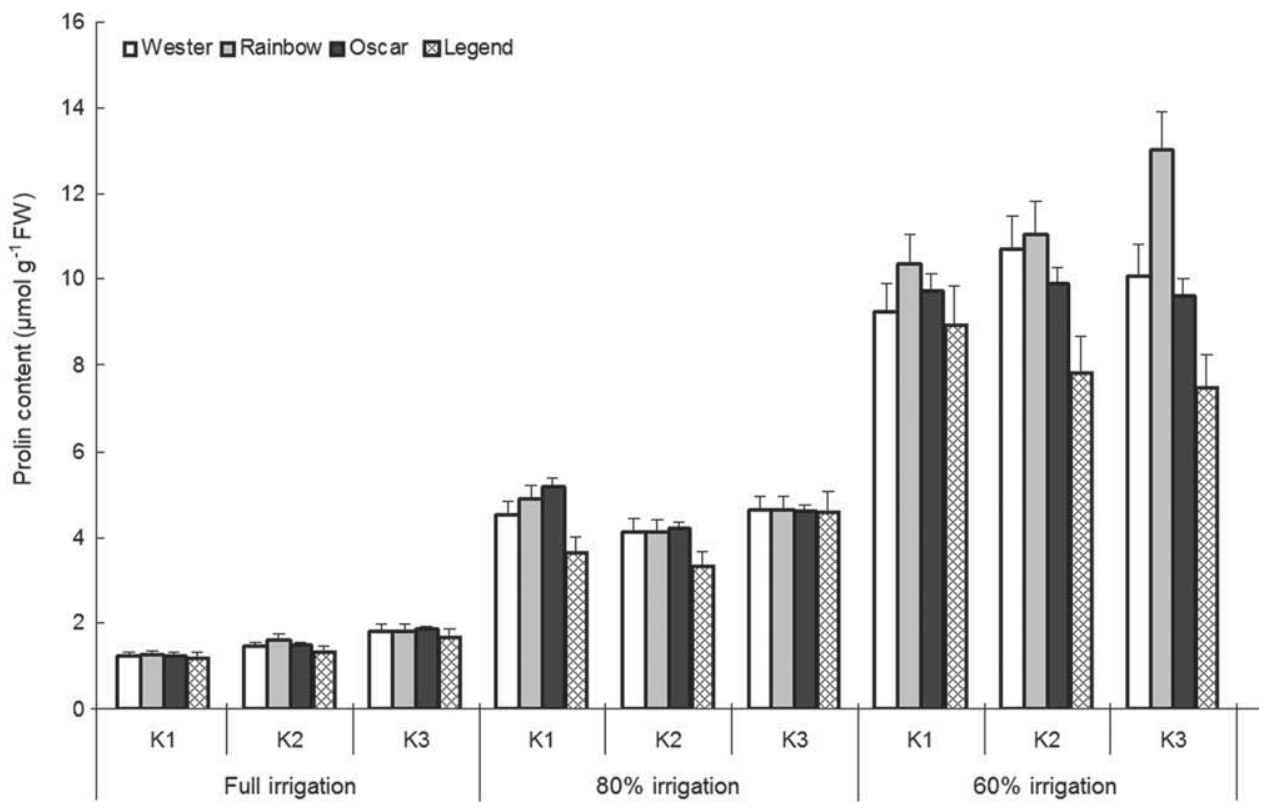

Fig. 4. Effect of water deficiency and potassium application and their interaction on shoot proline contents ( $\mu \mathrm{mol} \mathrm{g}{ }^{-1} \mathrm{FW}$ ) of Brassica napus cultivars ('Wester', 'Rainbow', 'Oscar' and 'Legend'). Potassium application: $60 \mathrm{~kg} \mathrm{ha}^{-1}$ (K1), $90 \mathrm{~kg} \mathrm{ha}^{-1}$ (K2), and $120 \mathrm{~kg} \mathrm{ha}^{-1}$ (K3). Bar represents \pm LSD at $\mathrm{p}<0.05$.

\section{Shoot sugar content}

Analysis of the data revealed that $\mathrm{K}$ application, irrigation and interaction between $\mathrm{I} \times \mathrm{C}$, $\mathrm{K} \times \mathrm{C}$ and $\mathrm{I} \times \mathrm{C} \times \mathrm{K}$ had a significant $(\mathrm{p}<0.05)$ effect on shoot sugar content of canola whereas the effect of interaction of $I \times K$ was non-significant $(p>0.05)$ (Fig. 5). Maximum shoot sugar content was produced by 'Rainbow' at $60 \%$ irrigation of actual evapotranspiration $\left(\mathrm{ET}_{\mathrm{a}}\right)$. In case of $\mathrm{K}$ application, maximum shoot sugar content was produced in plants treated with $120 \mathrm{~kg} \mathrm{~K} \mathrm{ha}^{-1}$. Similarly, maximum shoot sugar content was produced by 'Oscar' at $120 \mathrm{~kg} \mathrm{~K} \mathrm{ha}^{-1}$. 


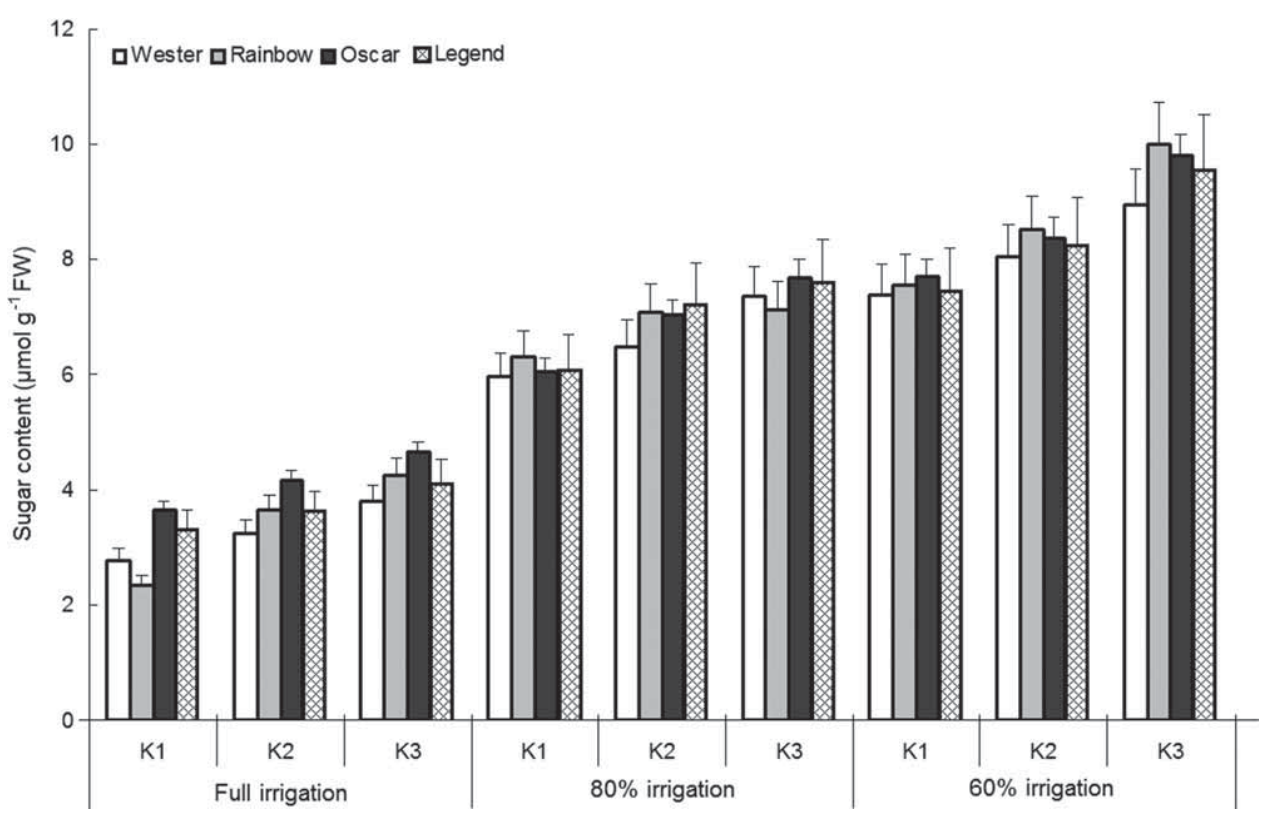

Fig. 5. Effect of water deficiency and potassium application and their interaction on shoot sugar contents ( $\left.\mu \mathrm{mol} \mathrm{g}{ }^{-1} \mathrm{FW}\right)$ of Brassica napus cultivars ('Wester', 'Rainbow', 'Oscar' and 'Legend'). Potassium application: $60 \mathrm{~kg} \mathrm{ha}^{-1}$ (K1), $90 \mathrm{~kg} \mathrm{ha}^{-1}$ (K2), and $120 \mathrm{~kg} \mathrm{ha}^{-1}$ (K3). Bar represents \pm LSD at $\mathrm{p}<0.05$.

\section{Relative water content of shoot}

Statistical analysis of the data showed that $\mathrm{K}$ application, irrigation and interaction between $\mathrm{I} \times \mathrm{C}, \mathrm{I} \times \mathrm{K}, \mathrm{K} \times \mathrm{C}$, and $\mathrm{I} \times \mathrm{C} \times \mathrm{K}$ had a significant $(\mathrm{p}<0.01)$ effect on relative water content (Fig. 6). The data revealed that maximum relative water content was observed in those treatments in which a $100 \%$ irrigation level was applied. Further, maximum relative water content was maintained by 'Wester' when applied with a 100\% irrigation level. In the case of interaction between $\mathrm{I} \times \mathrm{K}$, maximum relative water content was observed in plants treated with a $100 \%$ irrigation level and treated with $60 \mathrm{~kg} \mathrm{~K} \mathrm{ha}^{-1}$. Similarly, maximum relative water content was retained by 'Wester' when it was treated with $60 \mathrm{~kg} \mathrm{~K} \mathrm{ha}^{-1}$ and applied with $100 \%$ irrigation of actual evapotranspiration $\left(\mathrm{ET}_{\mathrm{a}}\right)$. Furthermore, it can be also inferred from the data that $\mathrm{K}$ application resulted in a decrease in RWC under full irrigation, but had a protective role under water deficit conditions, resulting in improvement of RWC.

\section{Grain yield}

Grain yield was significantly $(\mathrm{p}<0.01)$ affected by $\mathrm{K}$, irrigation and interaction between $\mathrm{I} \times \mathrm{C}, \mathrm{I} \times \mathrm{K}, \mathrm{K} \times \mathrm{C}$, and $\mathrm{I} \times \mathrm{C} \times \mathrm{K}$ (Fig. 7). Maximum grain yield (2093.9 $\mathrm{kg} \mathrm{ha}^{-1}$ ) was noted in $100 \%$ irrigated treatments. Similarly, grain yield was maximum $\left(2287.62 \mathrm{~kg} \mathrm{ha}^{-1}\right)$ in 'Oscar' when applied with $100 \%$ irrigation. Potassium application at $120 \mathrm{~kg} \mathrm{~K}^{-1}$ produced maximum grain yield $\left(1816.71 \mathrm{~kg} \mathrm{ha}^{-1}\right)$. The data also suggested that maximum grain yield (1995.62 $\mathrm{kg} \mathrm{ha}^{-1}$ ) was produced by 'Wester' when treated with $120 \mathrm{~kg} \mathrm{~K} \mathrm{ha}^{-1}$. In the 


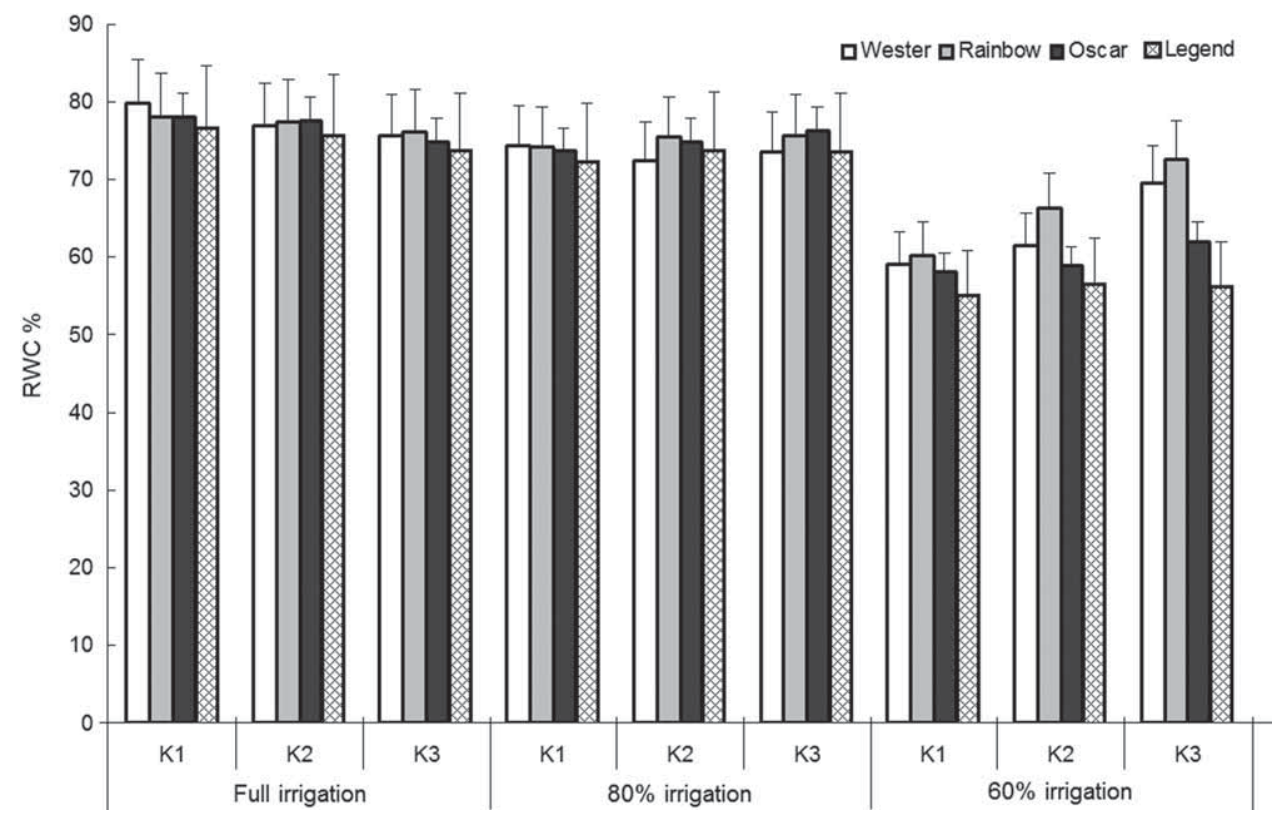

Fig. 6. Effect of water deficiency and potassium application and their interaction on shoot relative water content (RWC) of Brassica napus cultivars ('Wester', 'Rainbow', 'Oscar' and 'Legend'). Potassium application: $60 \mathrm{~kg} \mathrm{ha}^{-1}$ (K1), $90 \mathrm{~kg} \mathrm{ha}^{-1}$ (K2), and $120 \mathrm{~kg} \mathrm{ha}^{-1}$ (K3). Bar represents \pm LSD at $\mathrm{p}<0.05$.

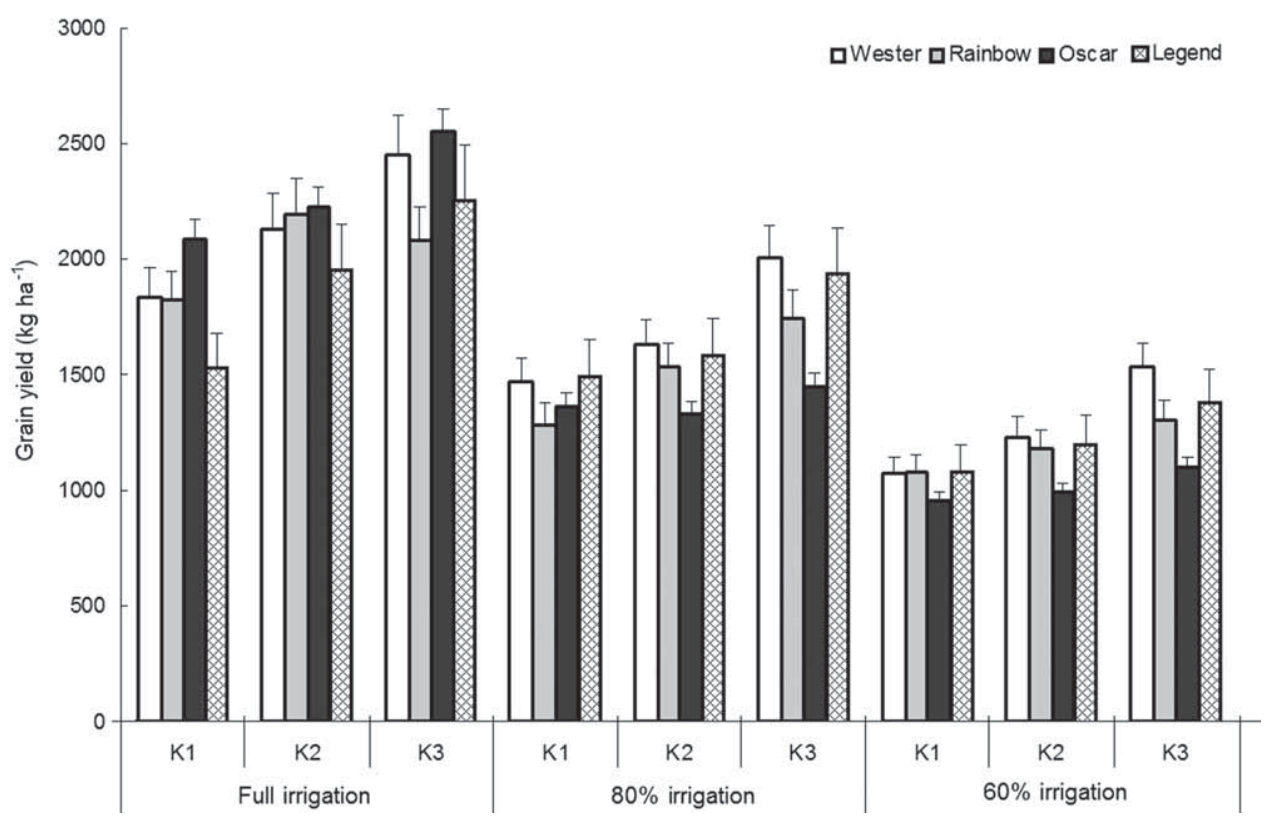

Fig. 7. Effect of water deficiency and potassium application and their interactions on grain yield $\left(\mathrm{kg} \mathrm{ha}^{-1}\right)$ of Brassica napus cultivars ('Wester', 'Rainbow', 'Oscar' and 'Legend'). Potassium application: $60 \mathrm{~kg} \mathrm{ha}^{-1}(\mathrm{~K} 1), 90 \mathrm{~kg} \mathrm{ha}^{-1}(\mathrm{~K} 2)$, and $120 \mathrm{~kg} \mathrm{ha}^{-1}(\mathrm{~K} 3)$. Bar represents $\pm \mathrm{LSD}$ at $\mathrm{p}<0.05$. 
case of I $\times \mathrm{K}$ interaction, maximum grain yield $\left(2335.1 \mathrm{~kg} \mathrm{ha}^{-1}\right)$ was noted in those plants which received $100 \%$ irrigation level and $120 \mathrm{~kg} \mathrm{~K} \mathrm{ha}^{-1}$. It is clear from the data that maximum grain yield $\left(2549.47 \mathrm{~kg} \mathrm{ha}^{-1}\right)$ was produced by 'Oscar' at 100\% irrigation level and $120 \mathrm{~kg} \mathrm{~K} \mathrm{ha}^{-1}$.

\section{Discussion}

Water deficiency increased proline concentration in all the cultivars of canola; however, this increase varied between the different cultivars. Accumulation of proline under stress conditions is used as an adaptive mechanism by many plant species (CHU et al. 1974, FrANCisCo et al. 2007, Ali et al. 2008, HASAn et al. 2008, BAKHT et al. 2011, ShAFI et al. 2011, BAKHT et al. 2012, BAKHT et al. 2013, HAYAT et al. 2013). Enhancement of proline concentration was noted in canola plants under drought stress at different growth stages (DiN et al. 2011). Difference in proline content of different cultivars may be due to up-regulation of degrading enzymes such as proline dehydrogenase. Proline is also considered as a storage compound of reduced $\mathrm{N}$ and carbon skeletons for post-stress growth recovery (VARTANIAN et al. 1992). Similarly, K application also increased proline concentration in all the cultivars in a dose dependent manner. However, the magnitude of increase was variable among the cultivars. Similar results are also reported by MukHerJee (1974), Wiemberg et al. (1988), and AzIz et al. (1999) who concluded that proline did not start to accumulate in leaves until the concentration of total monovalent cations, particularly of $\mathrm{K}$, in leaves reached a certain threshold levels. This might have happened in our study when the $\mathrm{K}$ level was increased from 60 to $120 \mathrm{Kg}$ per ha. The vital role of potassium in photosynthesis, translocation of photosynthates, protein synthesis, ionic balance, regulation of plant stomata and water use, activation of plant enzymes and many other processes is well recognized (MARSCHNER 1995, RedDy et al. 2004). Adequate K fertilization of crop plants facilitates osmotic adjustment, which maintains turgor pressure at lower leaf water potentials and improves the ability of plants to tolerate drought stress (Egilla et al. 2001, Mengel and ARneKe 1982). The promotion of root growth and protection of photosynthetic machinery and osmotic adjustment after enhanced $\mathrm{K}$ application under drought stress resulted in continued carbon fixation. Consequently, $\mathrm{K}$ application increased proline concentration at all water levels, the maximum being at $60 \% \mathrm{Et}_{\mathrm{a}}$.

Though $\mathrm{K}$ is the major osmoticum, accumulation of compatible solutes is an important component of the adaptive mechanism under drought stress conditions (McCuE and HANSON) 1990). Our results indicated that water deficit and interaction of $\mathrm{K}$ and water applied resulted in an increase in the sugar concentration in different cultivars. Fixation of assimilated carbon into a particular plant metabolite is determined by the capacity of the plant for photo assimilates production, which decreases under drought stress conditions. AKATSUKA and Nelson (1966) indicated that K increased starch synthetase activity and protected the enzyme from thermal inactivation. Biswas et al. (1992) reported increased sugar and starch content of sugarcane, tomatoes and potatoes under water stress. This increase in sugar concentration under drought stress may be due to increased production of starch. However, a negative correlation between sugar accumulation and starch content was noted in many plant species (SiLVA and ARRABACA 2004). Furthermore, K application enhances the ability of plants to produce assimilates resultantly increasing its ability of sugar production. Pro- 
tection of photosynthetic machinery and production of assimilates may be the major reasons for the increased accumulation of sugars under drought stress conditions. Allan et al. (2008) and RogIERs et al. (2011) reported that accumulation of sucrose was inversely correlated to leaf and root water status.

Relative water content of different canola cultivars decreased with a lowering of the irrigation levels under field conditions. Potassium application positively affected the RWC in all genotypes. Similarly, K application negatively affected RWC at full irrigation, but had a positive effect on RWC during decreasing water availability. Decreasing water availability and the continued need for gas exchange and cooling results in greater loss of water under drought stress conditions. Resultantly, a decrease in RWC was noted in this experiment, and even the enhanced production of proline and sugars under drought stress did not manage to maintain RWC. KAGE et al. (2004) attributed the difference in the leaf relative water content of rapeseed varieties to their root system variations. Decrease in the leaf relative water content in plants under water deficit has been reported (Allan et al. 2008). Furthermore, it can be also inferred from the data that K application resulted in a decrease in RWC under full irrigation, however, had a protective role under water deficit conditions resulting in improvement of RWC. The maintenance of plant water economy by K application in terms of a high RWC level under water deficiency condition could be ascribed to the supposed role of $\mathrm{K}$ in stomatal resistance, water use efficiency and lowered transpiration rate. These results are supported by UMAR and DIN (2002), who reported that application of K improves RWC of plants under water stress conditions. High drought stress intensity increases the potassium requirement for improving the water status and maintaining photosynthesis (UMAR 2006). Apart from the disorder in photosynthesis electron transport chain, the production of active oxygen formed by potassium deficiency is increased by NADPH oxidation (an important source for active oxygen production in plants subjected to potassium deficiency stress). It has been reported that plants become more susceptible to environmental stress in potassium deficient conditions (САKMAK 2005).

It can be inferred from the data that shoot fresh and dry weights were negatively affected by water deficit, but positively affected by $\mathrm{K}$ application. Furthermore, there was a negative effect of $\mathrm{K}$ application on shoot fresh and dry weight under full irrigation, and yet a positive effect was observed under water deficit conditions. Irrigation and irrigation and $\mathrm{K}$ interaction had significant effects whereas $\mathrm{K}$ application had a non significant effect on plant height of $B$. napus cultivars under study. It was further observed that there was a decrease in plant height with decreasing availability of irrigation water and an increase in plant height with increasing $\mathrm{K}$ application. When the different rates of $\mathrm{K}$ were applied with different irrigations, there was a decrease in plant height with increasing $\mathrm{K}$ application at full irrigation, but an increase in plant height with increasing K application at $80 \%$ or $60 \% \mathrm{ET}_{\mathrm{a}}$ supplementation through irrigation. Potassium has a positive role in turgidity maintenance and continual cell growth (Egilla et al. 2005, Fusheing 2006). Stomata closer in response to leaf turgor decline to high vapor pressure deficit in the atmosphere or to root-generated chemical signals, the latter being common in drought conditions (Chaves et al. 2009). Thus photosynthesis is one of the key processes to be affected by water deficit via decreased $\mathrm{CO}_{2}$ diffusion to the chloroplast and metabolic constraints. The relative impact of those limitations varies with the intensity of the stress, the occurrence (or not) of superimposed stresses, and the 
species. Furthermore, at the cellular level, though moderate water deficits had opposite effects on cell number and cell size, a more severe stress reduced both variables (AGUIRREZABAL et al. 2006). The decreased photosynthate production and assimilation thus reduced the growth of the seedlings, as evident in the lower fresh and dry weights. Fresh and dry weight data were collected at 60 days after sowing. At 60 days after sowing, most of the photosynthates are directed towards grains. Similarly, K application also affected photosynthate translocation positively, which might have reduced fresh and dry weight of the subject plant species (MARSCHNER et al. 1996). The osmotic adjustment through production of compatible solutes (proline and sugar) and increased $\mathrm{K}$ availability with application facilitates the maintenance of cell turgor during periods of water stress (TURNER and JONES 1980, MoRGAN 1984) and contributes to leaf survival by maintaining higher RWC at low water potentials (FLOWER and LuDLOw 1986, BASNAYAKE et al. 1993) and during recovery. The leaf survival also results in an increase in the absorption of sunlight, increasing the photo assimilates produced, which results in increased biomass production. Therefore, for plants growing in drought conditions, accumulation of abundant $\mathrm{K}$ in their tissues may play an important role in water uptake along a soil-plant gradient (FANAEI et al. 2009). Numerous studies have shown that the application of $\mathrm{K}$ fertilizer mitigates the adverse effects of drought on plant growth (ANDERSON et al. 1992, TiWARI et al. 1998, SANGAKKARA et al. 2001, EgILla et al. 2005, SingH and KuHAD 2005, FANAEI et al. 2009). Similarly, early maturation is one among the different mechanisms known to increase plant survival under water stress conditions (LEVITT 1980). Consequently, a decrease in number of days to $50 \%$ flowering and physiological maturity was noted in this experiment as well (data not shown). The acceleration of the flowering and/or maturity processes probably contributed to a reduction of the impact of drought stress in canola genotypes (MogHADAM et al. 2009).

Grain yield was negatively affected when the quantity of irrigation water was reduced. Potassium application positively increased grain yield at all irrigation levels; however, it is evident from the slope of the regression line that the unit increase with increasing quantity of $\mathrm{K}$ was more pronounced under drought stress conditions. The different physiological traits like photosynthesis, velocity and rate of assimilate transfer from source to sink determine seed yield (ChHABRA et al. 2007, AlbARRAK 2006). Furthermore, at any stage of crop growth such as germination, moisture stress can cause an irreversible loss in yield potential (Reginato 1983, Hosseini and Hassibi 2011, Khalil et al. 2012). Genotypic differences in efficiency of $\mathrm{K}$ uptake and utilization have been reported for all major economically important plants (RENGEL and DAMON 2008). NiKNAM et al. (2003) also showed that compared with $B$. napus, B. juncea genotypes maintained good yield under water deficit when osmotically adjusted. Potassium application under drought stress resulted in the protection of membranes resulting in increase in photosynthesis and enhanced partitioning of photo-assimilates to the roots (CAKMAK 2005). This would result in enhanced fixation of carbon and acquisition of nutrients from the soil. Resultantly, an increase in grain yield was noted with enhanced K application under drought stress. Furthermore, in addition to photosynthate production, the partitioning between different organs is also an important component of drought adaptation. Under stress conditions, the metabolic process are altered to produce substances involved in conferring protection and consequently, fewer resources are allocated to grain production. 


\section{References}

Aguirrezabal, L., Combaud, S. B., Radziejwoski, A., Dauzat, M., Cookson, S. J., Granier C., 2006: Plasticity to soil water deficit in Arabidopsis thaliana: dissection of leaf development into underlying growth dynamic and cellular variables reveals invisible phenotypes. Plant, Cell and Environment 29, 2216-2227.

Akatsuka, T., Nelson, O. E., 1966: Starch granule-bound adenosine diphosphate glucosestarch glucosyltransferases of maize seeds. Journal of Biological Chemistry 241, 2280 2286.

AlbARRAK, K. M., 2006: Irrigation interval and nitrogen level effects on growth and yield of canola (Brassica napus L.). Science Journal of King Faisal University 7, 87-99.

Aziz, A., Martin-Tanguy, J., Larher, F., 1999: Salt stress-induced proline accumulation and changes in tyramine and polyamine levels are linked to ionic adjustment in tomato leaf discs. Plant Science 145, 83-91.

Ali, B., Hayat, S., Fariduddin, Q., Ahmad A., 2008: 24-epibrassinolide protects against the stress generated by salinity and nickel in Brassica juncea. Chemospere 72, 1387-1392.

Allan, K. S. L., Candido, F. L. N., Benedito, G. S. F., Roberto, C. L. C., Flavio, J. R. C., Hadrielle, K. B. N., Monick, J. S. L., 2008: Physiological and biochemical behavior in soybean (Glycine max cv. Sambaiba) plant under water deficit. Australian Journal of Crop Science 2, 25-32.

Anderson, M. N., Jensen, C. R., Losch, R., 1992: The interaction effects of potassium and drought in field-grown barley. I. Yield, water-use efficiency and growth. Acta Agriculturae Scandinavica, Section B- Soil and Plant Science 42, 34- 44.

ArRAudeau, M. A., 1989: Breeding strategies for drought resistance in cereals. In: BAKER, F. W. G., (ed.), Drought resistance in cereals, 107-116. CAB International, Wallingford, UK.

Assmann, S. M., Shimazaki, K., 1999: The multisensory guard cell. Stomatal responses to blue light and abscisic acid. Plant Physiology 119, 809-816.

BAJJi, M., LutTs, S., Kinet, J. M. 2001: Water deficit effects on solute contribution to osmotic adjustment as a function of leaf ageing in three durum wheat (Triticum durum Desf) cultivars performing differently in arid conditions. Plant Science 160, 669-681.

BAKht, J., Shafi, M., JAmal, Y., Sher, H., 2011: Response of maize (Zea mays L.) to seed priming with $\mathrm{NaCl}$ and salinity stress. Spanish Journal of Agricultural Research 9, 252 261.

Bakht, J., Javed, M., Shafi, M., Mohammad, A. K., Mohammad, S., 2012: Effect of salinity and $\mathrm{ABA}$ application on proline production and yield in wheat genotypes. Pakistan Journal of Botany 44, 873-878.

Bakht, J., Bano, A., Shafi, M., Dominy, P., 2013: Effect of abscisic acid application on cold tolerance of chick pea (Cicer arietinum L.). European Journal of Agronomy 44, 10-21.

Basnayake, J., Ludlow, M. M., Cooper, M., Henzell, R. G., 1993: Genotypic variation of osmotic adjustment and desiccation tolerance in contrasting sorghum inbred lines. Field Crops Research 35, 51-62.

Bates, L. S., Waldren, R. P., Teare, I. D., 1973: Rapid determination of free proline for water stress studies. Plant and Soil 39, 205-208. 
Biswas, B. C., Prasad, N., Tewatia, R. K., 1992: Fertilizer use and crop quality. Fertilizer News 39, 47-49.

BRICKER, B., 1991: A micro-computer program for the design, management and analysis of agronomic experimentation. Michigan State University East Lansing Mi 48824 USA.

CAKMAK, I., 2005: The role of potassium in alleviating detrimental effects of abiotic stresses in plants. Journal of Plant Nutrition and Soil Science 168, 521-530.

Chaves, M. M., Flexas, J., Pinheiro, C., 2009: Photosynthesis under drought and salt stress: regulation mechanisms from whole plant to cell. Annals of Botany 103, 551-561.

Chhabra, M. L., Sinha, B. K., Singh, D., Dhawan, K., Sharma, R., 2007: Physiological constraints to productivity in Indian mustard (B. juncea L.). In: Tingdong F., Chunyun G. (eds.), Sustainable development in cruciferous oilseed crops production. Proceedings of the 12th International Rapeseed Congress, Hubei, Wuhan, China.

Chu, T. M., Aspinall, D., Paleg, L. G., 1974: Stress metabolism, temperature stress and accumulation of proline in barley and radish. Australian Journal of Plant Physiology 1, 89-97.

Din, J., Khan, S. U., Ali, I., Gurmani, A. R., 2011: Physiological and agronomic response of canola varieties to drought stress. The Journal of Animal and Plant Science 21, 7883.

Dubois, M., Gilles, K. A., Hamilton, J. K., Rebers, P. A., Smith, F., 1956: Colorimetric method for determination of sugars and related substances. Annals of Chemistry 38, 350-356.

Egilla, J. N., Davies, F. T., Drew, F. T., 2001: Effect of potassium on drought resistance of Hibiscus rosa-sinensis cv. Leprechaun: Plant growth, leaf macro and micronutrient content and root longevity. Plant and Soil 229, 213-224.

Egilla, J. N., Davies, F. T., Boutton, T. W., 2005: Drought stress influences leaf water content, photosynthesis, and water use efficiency of Hibiscus rosa-sinensis at three potassium concentrations. Photosynthetica 43, 135-140.

Fanaei, H. R., Galavi, M., Kafi, M., Bonjar, A. G., 2009: Amelioration of water stress by potassium fertilizer in two oilseed species. International Journal of Plant Production 3, 41-54.

Flower, D. J., Ludlow, M. M., 1986: Contribution of osmotic adjustment to the dehydration tolerance of water stressed pigeon pea leaves. Plant, Cell and Environment 9, 3340 .

FusheING, L., 2006: Potassium and water interaction. International Workshop on Soil Potassium and K Fertilizer Management, Agricultural College Guangxi University, 1-32.

Francisco, G. S., James, P. S., Vincente, G., Pablo, B., Jaun, G. P. P., 2007: Responses to flooding and drought stress by two citrus rootstock seedlings with different water-use efficiency. Physiologia Plantarum 130, 532-542.

Gibon, Y., Sulpice, R., Larher, F., 2000: Proline accumulation in canola leaf discs subjected to osmotic stress is related to the loss of chlorophylls and to the decrease of mitochondrial activity. Physiologia Plantarum 110, 469-476.

Glen, E., Brown, J., 1998: Effects of soil salt levels on the growth and water use efficiency of Atriplex canescens (Chenopodiaceae) varieties in drying soil. American Journal of Botany 85, 10-16. 
Gomez, K. A., Gomez, A. A., 1984: Statistical procedures for agricultural research. $2^{\text {nd }}$ Ed. John Willey \& Sons, Inc. New York, 641.

Hasan, S. A., Hayat, S., Ali, B., Ahmad, A., 2008: 28-homobrassinolide protects chickpea (Cicer arietinum) from cadmium toxicity by stimulating antioxidants. Environmental Pollution 151, 60-66.

Hayat, S., Hayat, Q., Alyemeni, M. N., Ahmad, A., 2013: Proline enhances antioxidative enzyme activity, photosynthesis and yield of Cicer arietinum L. exposed to cadmium stress. Acta Botanica Croatica 72, 323-335.

Hosseini, M., Hassibi, P., 2011: Effects of water deficit stress on several qualitative and quantitative characteristics of canola cultivars. Notulae Science Biology 3, 210-125.

JAMES, L. G. 1993: Principles of farm irrigation system design, Krieger, Malabar, Fla, USA.

Javadi, T., Arzani, K., Ebrahimzadeh, H., 2008: Study of proline, soluble sugar and chlorophyll $\mathrm{a}$ and $\mathrm{b}$ changes in nine Asian and one European peer cultivar under drought stress. Acta Horticulturae 769, 241-246.

Kage, H., Kochler, M., Stutzel, H., 2004: Root growth and dry matter partitioning of cauliflower under drought stress conditions: measurement and simulation. European Journal of Agronomy 20, 379-394.

Keyvan, S., 2010: The effects of drought stress on yield, relative water content, proline, soluble carbohydrates and chlorophyll of bread wheat cultivars content, proline, soluble carbohydrates and chlorophyll of bread wheat cultivars. The Journal of Animal and Plant Science 8, 1051-1060.

Khalil, M., Aboughadareh, A. P., Naghavi, M. R., Talebzadeh, S. J., 2012: Response of spring canola (Brassica napus L.) genotypes to water deficit stress. International Journal of Agriculture and Crop Science 4, 1579-1586.

LeVITT, J., 1980: Response of plants to environmental stresses. Vol. II. Water, radiation, salt and other stresses responses of plants to environmental stresses. $2^{\text {nd }}$ Edition, Academic Press, New York.

Mafakheri, A., Siosemardeh, A., Bahramnejad, B., Struik, P. C., Sohrabi, E., 2010: Effect of drought stress on yield, proline and chlorophyll contents in three chickpea cultivars. Australian Journal of Crop Science 4, 580-585.

Marschner, H., 1995: Mineral nutrition of higher plants. $2^{\text {nd }}$ Ed. Academic Press, San Diego, California, USA.

Marschner, H., Kirkby, E. A., CAKMAK, I. 1996. Effect of mineral nutrition status on shootroot partitioning of photoassimilates and cycling of mineral nutrients. Journal of Experimental Botany 47, 1255-1263.

McCue, K. F., Hanson, A. D., 1990: Drought and salt tolerance: towards understanding and application. Trends in Biotechnology 8, 358-362.

Mengel, K., Arneke, W. W., 1982: Effect of potassium on the water potential, pressure potential, osmotic potential and cell elongation in leaves of Phaseolus vulgaris L. Phyisologia Plantarum 54, 402-408.

Moghadam, H. R. T., Rad, A. H. S., Mohammadi, G. N., Habibi, D., Sanavy, S. A. M., BooJar, M. M. A., Dolatabadian A., 2009: Response of six oilseed rape genotypes to water stress and hydrogel application. Prsquisa Agropecuaria Tropical Goiania (Agricultural Research in the Tropics) 39, 243-250. 
Monreal, J. A., Jimenez, E. T., Remesal E., Monrillo-Vlarde, R., Garcia-Maurino, S., ECHEVANRRIA, C., 2007: Proline content of sugar beet storage roots: Response to water deficit and nitrogen fertilization at field conditions. Environmental and Experimental Botany 60, 257-267.

Morgan, J. M., 1984: Osmoregulation and water stress in higher plant. Annual Review of Plant Physiology 35, 299-319.

Moustakas, M., Ilektra, S., Theodora, K., Chrysovalantou, I. A., Ioannis, T., 2011: Exogenous proline induces soluble sugar accumulation and alleviates drought stress effects on photosystem II functioning of Arabidopsis thaliana leaves. Plant Growth Regulation $65,315-325$.

MuKHERJEe, I., 1974. Effect of potassium on proline accumulation in maize during wilting. Physiologia Plantarum 31, 288-291.

Niknam, S. R., MA, Q., Turner, D. W., 2003: Osmotic adjustment and seed yield of Brassica napus and B. juncea genotypes in water-limited environment. Australian Journal of Experimental Agriculture 43, 1127-1135.

Outlaw JR. W. H., 1983: Current concepts on the role of potassium in stomatal movements. Physiologia Plantarum 59, 302-311.

Reddy, A. R., Chaitany, K. V., Vivekanandan, M., 2004: Drought induced responses of photosynthesis and antioxidant metabolism in higher plants. Journal of Plant Physiology 161, 1189-1202.

Reginato, R. J., 1983: Field quantification of crop water stress. Transactions of American Society for Agricultural Engineers 26, 772-775.

Rengel, Z., Damon, P. M., 2008: Crops and genotypes differ in efficiency of potassium uptake and use. Physiologia Plantarum 133, 624-636.

Rogiers, S. Y., Holzapfel, B. P., Smith, J. P., 2011: Sugar accumulation in roots of two grape varieties with contrasting response to water stress. Annals of Applied Biology $159,399-413$.

Ronde, J. A., Laurie, R. N., Caetano, T., Greyling, M. M., Kerepesi, I. 2004: Comparative study between transgenic and non-transgenic soybean lines proved transgenic lines to be more drought tolerant. Euphytica 138, 123-132.

SAngakkara, U. R., Frehner, M., Nosbrger, J., 2001: Influence of soil moisture and fertilizer potassium on the vegetative growth of mungbean (Vigna radiata L. Wilczek) and cowpea (Vigna unguiculata L. Walp). Journal of Agronomy and Crop Science 186, 7381.

Sarker, A. M., Rahman, M. S., Paul, N. K., 1999: Effect of soil moisture on relative leaf water content, chlorophyll, proline and sugar accumulation in wheat. Journal of Agronomy and Crop Science 183, 225-229.

Shafi, M., BaKht, J., Javed, M., Mohammad, A. K., Razi, D., 2011: Role of abscisic acid and proline in salinity tolerance of wheat genotypes. Pakistan Journal of Botany 43, $1111-1118$.

Silva, J. M., Arrabaca, M. C., 2004: Contribution of soluble carbohydrates to the osmotic adjustment in the C4 grass Setaria sphacelata: A comparison between rapidly and slowly imposed water stess. Journal of Plant Physiology 161, 551-555. 
Singh, N., KuHAD, M. S., 2005: Role of potassium in alleviating the effect of water stress on yield and seed quality in chickpea (Cicer arietinum L.). Bulletin of National Institute of Ecology 15, 219-225.

Sofo, A., Bartolmeo, D., Cristos, X., Andrea, M., 2004: Lipoxygenase activity and proline accumulation in leaves and roots of olive trees in response to drought stress. Physiologia Plantarum 121, 58-65.

Steel, R. G. D., Torrie, J. H., 1997: Principles and procedures of statistics: A biochemical approach. McGraw Hill, New York, USA.

Tiwari, H. S., Agarwa, R. M., Bhatt, R. K., 1998: Photosynthesis, stomatal resistance and related characteristics as influenced by-potassium under normal water supply and water stress conditions in rice (Oryza sativa L.). Indian Journal of Plant Physiology 3, 314316.

Turner, N. C., Jones M. M., 1980: Turgor maintenance by osmotic adjustment. In: Turner, N. C. And Kramer, P. J. (eds.), Adaptation of plants to water and high temperature stress, 87-103. John Wiley \& Sons Inc, New York.

UMAR, S., 2006: Alleviation adverse effects of water stress on yield of sorghum, mustard and groundnut by potassium application. Pakistan Journal of Botany 38, 1373-1380.

UMAR, S. Din, M., 2002: Genotypic differences in yield and quality of groundnut as affected by potassium nutrition under erratic rainfall conditions. Journal of Plant Nutrition 25, $1549-1562$.

Vartanian, N., Hervochon, P., Marcotte, L. Larher, F., 1992: Proline accumulation during drought rhizogenesis in Brassica napus var. oleifera. Journal of Plant Physiology $140,623-628$.

Weimberg, R., Lerner, H. R., Poljakoff-Mayber, A., 1988: A relationship between potassium and proline accumulation in salt-stressed Sorghum bicolor. Physiologia Plantarum $55,5-10$. 